\title{
Grinding Parameters and their Effects on the Quality of Corn for Feed Processing
}

\author{
Dabbour MI*, Bahnasawy A, Ali S and El-Haddad Z
}

Agricultural Engineering Department, Faculty of Agriculture, Benha University, Egypt

\begin{abstract}
The experiments of this study were carried out to optimize some grinding parameters and their effects on the quality of corn for feed processing. The hammer mill was evaluated under different parameters including grain moisture content and sieve hole diameter. Grinding process was evaluated by studying the performance, energy consumption, grinding index, grinding ability index, ground quality at different operation conditions. The results revealed that the mill performance, specific energy, energy density, grinding index and grinding ability index ranged from 0.70-6.83 Mg/h, 3.38-32.72 kJ/kg, 1.99-18.82 MJ/m³, $12.35-91.28$ $\mathrm{kJ} . \mathrm{mm}^{0.5} \mathrm{~kg}$ and $0.81-6.00 \mathrm{~kJ} / \mathrm{m}^{2}$, respectively. Mean weight diameter, size reduction, bulk density and grinding effectiveness ranged from 1.47-2.89 mm, 2.60-5.10 times, $524.58-621.34 \mathrm{~kg} / \mathrm{m}^{3}$ and $8.88-14.40$, respectively at different sieve hole diameter and grain moisture content.
\end{abstract}

Keywords: Grinding; Energy consumption; Performance; Fineness degree; Size reduction

\section{Introduction}

Grinding is one of the most important and energy-consuming processes in cereal industry. This process consumes from $70 \%$ of total power during the feed production up to $90 \%$ during wheat flour milling. The grinding energy requirements depend on kinematical and geometrical parameters of the grinding machine and physical properties of the ground material. Knowledge of the grinding properties of grain is essential to adjust the correct parameters of grinding and sieving machines. It is the best way to produce higher and better-quality product yields at minimum energy requirements. From among the physical properties, the mechanical ones have the greatest influence on grinding energy consumption. These properties depend mainly on a cultivar, but also form agroclimatic and agro-technical factors. Wetting or drying the grains can also modify them [1-7] found that increasing the screen size of hammer mill from 3.2 to 4.8 and 6.33 $\mathrm{mm}$ gave a decrease of 30 and $55 \%$ in grinding energy under operating conditions at drum speed $2930 \mathrm{rpm}$, no. of hammers 12 hammer and moisture content $5.1 \%$. Increasing of drum speed from 1460 to 2930 and $3910 \mathrm{rpm}$ gave a decrease of 59.1 and $67.9 \%$ in grinding energy under operating conditions at screen size of $6.35 \mathrm{~mm}$, no. of hammers 12 hammers and grain moisture content $5.4 \%$. Increase of the grain moisture content from 5.4 to 8.1 and $11.4 \%$ gave an increase of 20.1 and $49 \%$ in grinding energy under operating conditions at drum speed 2930 $\mathrm{rpm}$, screen size $6.35 \mathrm{~mm}$, no. of hammers 12 hammers. Increasing of no. of hammers from 6 to 8,10 and 12 hammers gave a decrease of 22.8 , 39.5 and $50.4 \%$ in grinding energy under operating conditions at drum speed $2930 \mathrm{rpm}$, screen size $6.35 \mathrm{~mm}$ and grain moisture content $5.1 \%$. And he added that higher fineness of grinding \% (fine) was obtained at lower grain moisture content and higher drum speed. In addition, as to fineness degree of grinding (medium and coarse) an opposite trend results comparing with the fineness degree of grinding (fine).

Comparing the specific energy, grinding rate, and particle size using a hammer mill with two hammer thickness scenarios: 3.2 and 6.4 $\mathrm{mm}$. The average specific energy for thin hammer tests was $10.2 \mathrm{~kW} \mathrm{~h} /$ $\mathrm{Mg}$, which was $13.6 \%$ less than that of the thick hammer $(11.8 \mathrm{~kW} \mathrm{~h} /$ $\mathrm{Mg}$ ). The grinding rate was higher for the thin hammer configuration $[8,9]$ reported that the specific grinding energy of uncrushed kernels ranged from 72.3 to $146.7 \mathrm{~kJ} \cdot \mathrm{kg}^{-1}$ and from 67.0 to $114.4 \mathrm{~kJ} \cdot \mathrm{kg}^{-1}$ for
Turnia and Slade, respectively. The crushing caused a decrease of specific grinding energy in both cultivars. The total specific grinding energy of crushed kernels (the sum of crushing energy and grinding energy) ranged from 47.6 to $100.5 \mathrm{~kJ} \cdot \mathrm{kg}^{-1}$ and from 44.6 to $85.3 \mathrm{~kJ} \cdot \mathrm{kg}^{-1}$ for hard and soft wheat, respectively. In addition, the other grinding energy indices confirmed that crushing of kernels prior to hammer mill grinding considerably reduced the grinding energy requirements. Kilborn et al. [4] found that the total specific milling energy ranged from $46 \mathrm{~kJ} \cdot \mathrm{kg}^{-1}$ for soft wheat cultivars to $124 \mathrm{~kJ} \cdot \mathrm{kg}^{-1}$ for durum wheat.

The results concerning the influence of grain mechanical properties on wheat grinding energy requirements. The investigations were carried out on 10 wheat varieties (grain moisture was $15 \%$ ). The results showed that the specific grinding energy ranged from 22 to $37 \mathrm{~kJ} . \mathrm{kg}^{-1}$. The grinding efficiency index ranged from 0.215 to 0.342 $\mathrm{m}^{2} \cdot \mathrm{kg}^{-1}[10,11]$ reported that wheat and barley straws, corn stover and switchgrass at two moisture contents were ground using a hammer mill with three different screen sizes $(3.2,1.6$ and $0.8 \mathrm{~mm})$. Energy required for grinding these materials was measured. Among the four materials, switchgrass had the highest specific energy consumption $(27.6 \mathrm{~kW} \mathrm{~h}$ $\left.\mathrm{t}^{-1}\right)$, and corn stover had the least specific energy consumption (11.0 $\mathrm{kW} \mathrm{h} \mathrm{t} \mathrm{t}^{-1}$ ) at $3.2 \mathrm{~mm}$ screen size [12] studied the effect of the operational parameters on the fineness of the ground corn. The screen opening size was the most significant factor effect on the ground corn fineness. The screen opening size of $14 \mathrm{~mm}$, number of hammers of 45 and the speed of $28.6 \mathrm{~m} / \mathrm{s}$ resulted in medium ground corn fineness.

The main aim of this study is to investigate the effect of grinding parameters on the performance, energy consumption and ground quality.

*Corresonding author: Mokhtar Ibrahim Dabbour, Agricultural Engineering Department, Faculty of Agriculture, Benha University, Egypt, E-mail: mokhtar.dabbour@fagr.bu.edu.eg

Received April 28, 2015; Accepted July 03, 2015; Published July 10, 2015

Citation: Dabbour MI, Bahnasawy A, Ali S, El- HaddadZ (2015) Grinding Parameters and their Effects on the Quality of Corn for Feed Processing. J Food Process Technol 6: 482. doi:10.4172/2157-7110.1000482

Copyright: (c) 2015 Dabbour MI, et al. This is an open-access article distributed under the terms of the Creative Commons Attribution License, which permits unrestricted use, distribution, and reproduction in any medium, provided the original author and source are credited. 


\section{Materials and methods}

The main experiment was carried out at the Feed Manufacturing Plant, Faculty of Agriculture, Moshtohor, Benha University, Egypt during the period from October to February, 2012- 2013 to optimize some grinding parameters and their effects on the quality of corn for feed processing.

\section{Materials}

Corn grain: Experiments were carried out on yellow corn grain different moisture contents.

Hammer mill prototype: Figure 1 show the schematic diagram of the hammer mill which consists of hammer tip, rotor, hammers and screen. The hammer tip diameter is $47 \mathrm{~cm}$ and the mill width is $70 \mathrm{~cm}$. The rotor carries four rows of rectangular hammers with a width of 4.3 $\mathrm{cm}$ and a length of $15 \mathrm{~cm}$. The hammers swing about their pivots while the rotor is rotating. The specification of the hammer mill are listed in Table 1.

Measuring devices: Vernier caliper (model DIN 862, measuring range $0-150 \mathrm{~mm}$ with an accuracy of $\pm 0.05 \mathrm{~mm}$ ) was used to measure the diameter of different sieve holes, diameter of different die holes and dimensions of corn grains. The power requirement $(\mathrm{kW})$ was determined by recording the voltage and current strength by using the clamp meter (made in China, Model DT266, Measuring range $200 / 1000 \mathrm{~A}$ and $750 / 1000 \mathrm{~V}$ with an accuracy of \pm 0.01 ) to measure the line current strength (I) and the potential difference value (V). Two digital balances were used during the experiment execution. Balance (1) (made in China, Model YH-T7E, measuring range of $0-300 \mathrm{~kg}$ $\pm 0.05 \mathrm{~kg})$ It was used to determine the mass of the ground grains before grinding process. Balance (2) (made in Japan, model CG-12K, measuring range of $0-12 \mathrm{~kg} \pm 0.001 \mathrm{~kg}$ ). It was used to determine the mass of the ground grains after grinding process (samples $200 \mathrm{~g}$ ). Grain moisture tester (made in Japan, model PM 300 and accuracy \pm 0.2 $0.5 \%$ ) It is used to record moisture content for grains. Standard testing sieve(made in Egypt, No. of sieves 5 and measuring range of $1-7 \mathrm{~mm}$ ) used to clear grinding grain for measuring the fineness degree, mean weight diameter and size reduction ratio.

\section{Methods}

The hammer mill was evaluated at three sieve holes diameter $(4,6$ and $8 \mathrm{~mm}$ ) and three levels of corn moisture contents (10, 14 and $18 \%$ w.b).The mill productivity is determined by dividing the product mass by time; $\mathrm{Mg} / \mathrm{h}$.

The specific energy consumption: Electrical power consumption was estimated from the measured electric current and voltage values and estimated according to [13] as follows from equation:

$$
E p=\frac{\sqrt{3} * I * V * \eta * \cos \varphi}{1000}
$$

Where Ep is the electrical power, $\mathrm{kW}, \mathrm{I}$ is the electric current, Amperes, $\eta$ the mechanical efficiency assumed to be 0.95 [14], $V$ the electrical voltage, $\mathrm{V}$ and $\cos \varphi$ the power factors being equal to (0.84).

The specific energy consumption $(\mathrm{kJ} / \mathrm{kg})$ was calculated by using the following equation:

$$
\text { The specific energy consumption }=\frac{\text { Total energy consumption }}{\text { Productivity }}
$$

Energy density consumption: The energy density consumption $\left(\mathrm{kJ} / \mathrm{m}^{3}\right)$ was calculated by using the following equation:

$$
E d=S E C^{*} \rho
$$

Where Ed is the energy density, $\mathrm{kJ} / \mathrm{m}^{3}, \rho$ the bulk density of the ground material, $\mathrm{kg} / \mathrm{m}^{3}$ and $\emptyset_{i}$ represents the differential weight fraction, $\mathrm{kg} / \mathrm{kg}$.

Fineness degree (particle size distribution): The ground corn samples were classified in to five main grades on the basis of modulus of fineness as follow: [(particle size $<1 \mathrm{~mm}),(1<$ particle size $<2 \mathrm{~mm})$, ( $2<$ particle size $<3 \mathrm{~mm}),(3<$ particle size $<5 \mathrm{~mm})$ and $(5<$ particle size $<7 \mathrm{~mm}$ )]. Each grade was weighed and percentage of each class was calculated.

Mean weight diameter: To determine the mean weight diameter, the ground corn samples were classified in to five main grades on the basis of modulus of fineness starting from particle size less than $1 \mathrm{~mm}$ to larger than $5 \mathrm{~mm}$. The total weight of samples and the mass of each product categories were weighed using a precise digital scale with an accuracy of $0.001 \mathrm{~kg}$. The percent distribution of each fraction was determined by dividing the fraction's mass with the total mass of the output product according to [15] from the following equation.

$$
M W D=\sum_{i=1}^{n} \varnothing_{i} d_{i}
$$

Where MWD is the mean weight diameter, $m m$ and $d_{i}$ the particles
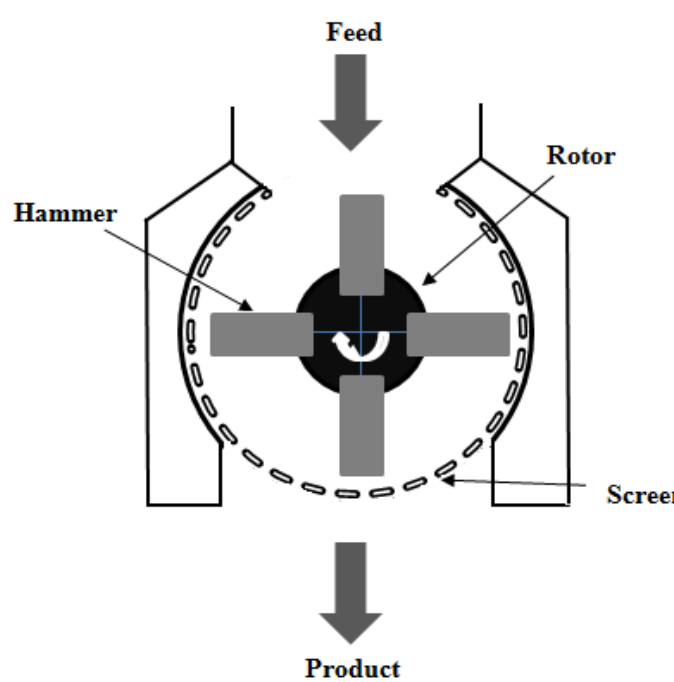

Figure 1: Schematic diagram of the hammer mill.

\begin{tabular}{|c|c|}
\hline Items & Values \\
\hline Screen length, cm & 136 \\
\hline Screen width, cm & 20 \\
\hline Mill diameter, cm & 50 \\
\hline Rotor speed, rpm & 1450 \\
\hline Number of rows & 4 \\
\hline Number of hammers in each row & 4 \\
\hline Rotor width, cm & 15 \\
\hline Source of power & AC Motor (20 hp) \\
\hline Knives shape & Rectangular \\
\hline Knives width, cm & 4.3 \\
\hline Knives length, cm & 15 \\
\hline Knives thickness, cm & 0.7 \\
\hline
\end{tabular}

Table 1: The hammer mill specifications. 
Citation: Dabbour MI, Bahnasawy A, Ali S, El- HaddadZ (2015) Grinding Parameters and their Effects on the Quality of Corn for Feed Processing. J Food Process Technol 6: 482. doi:10.4172/2157-7110.1000482

Page 3 of 7

passing through the aperture size, $\mathrm{mm}$.

Size reduction ratio: The size reduction ratio, which is the ratio of initial to final particle size. The size reduction ratio was estimated according to [16] as follows from equation:

$\frac{\text { Average size of the corn }}{\text { Average size of the product }}$

Where $S_{R}$ is the size reduction, times.

Grinding ability index: The grinding ability index was calculated as a ratio of the grinding energy to the surface area of the pulverized material described by [17]

$$
G A I=\frac{S E C^{*} \rho^{*} M W D}{6}
$$

Where GAI is the grinding ability index, $\mathrm{kJ} / \mathrm{m}^{2}$, SEC the specific energy consumption, $\mathrm{kJ} / \mathrm{kg}$ and $\rho$ the bulk density of the grinding material, $\mathrm{kg} / \mathrm{m}^{3}$.

Grinding index: The grinding index was calculated on the basis of the size reduction theory described by [18].

$$
\begin{gathered}
G I=\frac{S E C}{\frac{1}{\sqrt{M W D}}-\frac{1}{\sqrt{D}}} \\
D=\left(\frac{1}{\sum_{j} \frac{G_{j}}{\sqrt{D_{j}}}}\right)^{2}
\end{gathered}
$$

Where GI is the grinding index, $\mathrm{kJ} . \mathrm{mm}^{0.5} / \mathrm{kg}, \mathrm{G}_{\mathrm{j}}$ the mass fraction

of a particular size class $j, \mathrm{~kg} / \mathrm{kg}, \mathrm{D}_{\mathrm{j}}$ represents the size of the fraction, $\mathrm{mm}$ and $\mathrm{D}$ the average particle size of the material before grinding, $\mathrm{mm}$.

Grinding effectiveness: The grinding effectiveness, which is the ratio of final to initial surface area. The grinding effectiveness was estimated according to [19] as follows:

$$
\text { Grinding effectiveness }=\frac{\text { Surface area after grinding }}{\text { Surface area before grinding }}
$$

The surface area after grinding was calculated according to [19] as follows:

Surface area after grinding $=4 \pi\left(\frac{M W D}{2}\right)^{2} N$

Number of particles $(N)=\frac{\text { Weight of single grain }}{\text { Weight of single particle }}$

Weight of single particle $=\frac{4}{3} \pi\left(\frac{M W D}{2}\right)^{3} \rho$

The surface area before grinding was calculated according to [20] as follows:

$$
\text { Surface area before grinding }=\frac{\pi B L^{2}}{(2 L-B)}
$$

$$
B=\sqrt{W T}
$$

Where $\mathrm{L}$ is the length of single grain, $\mathrm{mm}, \mathrm{W}$ the width of single grain, $\mathrm{mm}$ and $\mathrm{T}$ the thickness of single grain, $\mathrm{mm}$.

\section{Results and Discussions}

\section{Hammer mill evaluation}

The mill was evaluated by studying the relationship between the mill performance, energy consumption, grinding index, grinding ability index and ground product quality (mean weight diameter, fineness degree, size reduction, bulk density and grinding effectiveness).

Performance, specific energy and energy density consumption: Figures 2-4 show the effect of sieve hole diameter and cereal moisture content on the performance, the specific energy and energy density consumption of the hammer mill. It could be seen that the mill performance decreased with increasing the moisture content and increased by increasing sieve hole diameter, where it decreased from 1.44 to $0.70 \mathrm{Mg} / \mathrm{h}$ at $4 \mathrm{~mm}$ hole diameter, from 3.02 to $1.61 \mathrm{Mg} / \mathrm{h}$ at $6 \mathrm{~mm}$ hole diameter and it decreased from 6.83 to $4.38 \mathrm{Mg} / \mathrm{h}$ at $8 \mathrm{~mm}$ sieve hole diameter when the moisture increased from 10 to $18 \%$. The reduction percentage was $51.40 \%$ at $4 \mathrm{~mm}$ hole diameter, $46.70 \%$ at

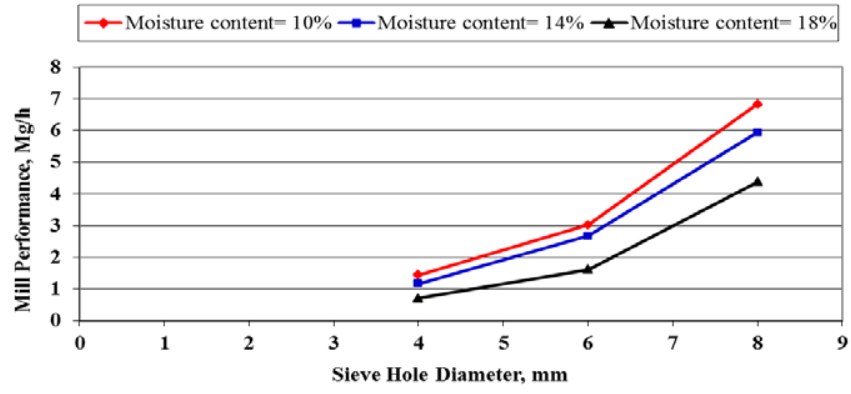

Figure 2: Effect of moisture content and sieve holes diameter on mill performance.

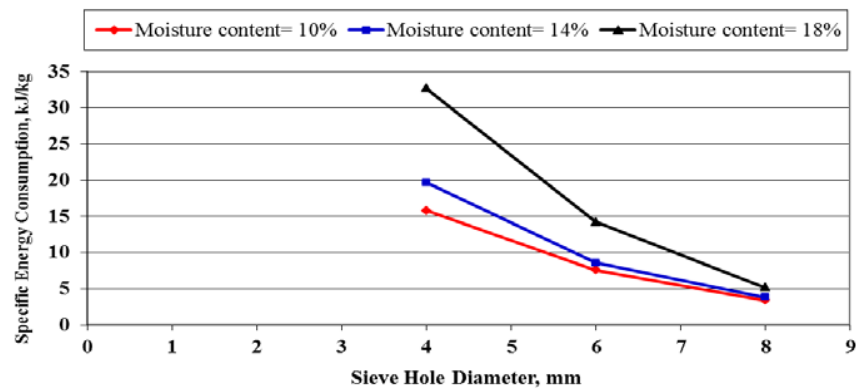

Figure 3: Effect of moisture content and sieve holes diameter on specific energy consumption of corn grinding.

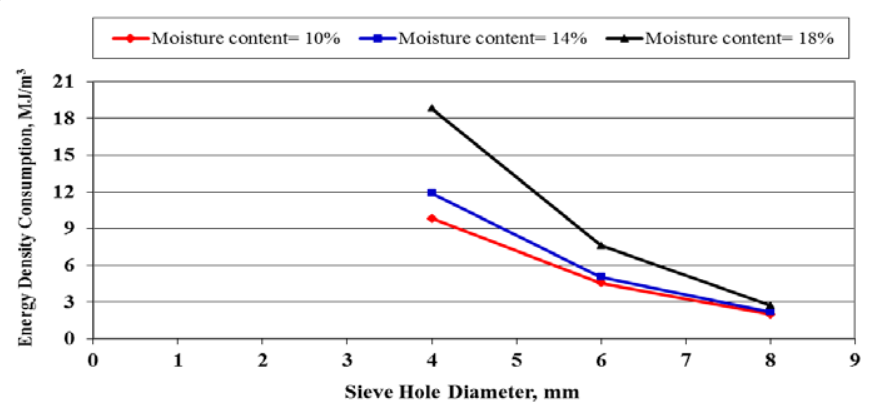

Figure 4: Effect of moisture content and sieve holes diameter on energy density consumption. 
$6 \mathrm{~mm}$ and $35.90 \%$ at $8 \mathrm{~mm}$ hole diameter. Meanwhile the increasing percentage due to the effect of sieve hole diameter was $78.92 \%$ at $10 \%$ moisture content, $80.47 \%$ at $14 \%$ moisture content and $84.02 \%$ at $18 \%$ moisture content.

These results could be attributed to that the increase of grain moisture content caused an increase of grain plasticity and thus difficulties with grinding therefore needs more time to complete grinding, which leads to lower productivity of the hammer mill [21].

Multiple regression was carried out to find a relationship between the mill performance and both the moisture content (10-18\%) and sieve hole diameter $(4-8 \mathrm{~mm})$. the most suitable form obtained was as follows:

$$
\mathrm{Mp}=1.39(\mathrm{Ds})-0.20(\mathrm{Mc})-0.94 \quad\left(\mathrm{R}^{2}\right)=0.92
$$

Where $\mathrm{Mp}$ is the mill performance, $\mathrm{Mg} / \mathrm{h}$, Ds sieve hole diameter, $\mathrm{mm}$ and Mc moisture content, $\%$.

Regarding the specific energy consumption, the results indicated that the specific energy consumption increased with increasing the moisture content and decreased with increasing the sieve hole diameter, where it increased from 15.83 to $32.72 \mathrm{~kJ} / \mathrm{kg}$ at $4 \mathrm{~mm}$ hole diameter, from 7.57 to $14.24 \mathrm{~kJ} / \mathrm{kg}$ at $6 \mathrm{~mm}$ hole diameter and it increased from 3.38 to $5.20 \mathrm{~kJ} / \mathrm{kg}$ at $8 \mathrm{~mm}$ sieve hole diameter when the moisture increased from 10 to $18 \%$. The increasing percentage was $51.62 \%$ at $4 \mathrm{~mm}$ hole diameter, $46.84 \%$ at $6 \mathrm{~mm}$ and $35.00 \%$ at $8 \mathrm{~mm}$ hole diameter. Meanwhile the reduction percentage due to the effect of sieve hole diameter was $78.65 \%$ at $10 \%$ moisture content, $80.47 \%$ at $14 \%$ moisture content and $84.11 \%$ at $18 \%$ moisture content.

This may be due to the fact that the increase in moisture content causes increase in kernel plasticity therefore increases the shear strength of the corn grain, which leads to higher energy consumption for grinding $[1,2,22]$. These results trend agreed with those obtained by $[7,21]$.

Multiple regression was carried out to find a relationship between the specific energy consumption and both the moisture content (10- 18\%) and sieve hole diameter $(4-8 \mathrm{~mm})$. the most suitable form obtained was as follows:

$$
\mathrm{SEC}=-4.89(\mathrm{Ds})+0.94(\mathrm{Mc})+28.81 \quad\left(\mathrm{R}^{2}\right)=0.87
$$

Where SEC is the specific energy consumption, $\mathrm{kJ} / \mathrm{kg}$.

Regarding the energy density consumption, the results indicated that the energy density consumption increased with increasing the moisture content and decreased with increasing the sieve hole diameter, where it increased from 9.84 to $18.82 \mathrm{MJ} / \mathrm{m}^{3}$ at $4 \mathrm{~mm}$ hole diameter, from 4.56 to $7.61 \mathrm{MJ} / \mathrm{m}^{3}$ at $6 \mathrm{~mm}$ hole diameter and it increased from 1.99 to $2.73 \mathrm{MJ} / \mathrm{m}^{3}$ at $8 \mathrm{~mm}$ sieve hole diameter when the moisture increased from 10 to $18 \%$. The increasing percentage was $47.72 \%$ at 4 $\mathrm{mm}$ hole diameter, $40.08 \%$ at $6 \mathrm{~mm}$ and $27.12 \%$ at $8 \mathrm{~mm}$ hole diameter. Meanwhile the reduction percentage due to the effect of sieve hole diameter was $79.78 \%$ at $10 \%$ moisture content, $81.57 \%$ at $14 \%$ moisture content and $85.49 \%$ at $18 \%$ moisture content.

Grinding index and grinding ability index: Figures 5 and 6 show the effect of sieve hole diameter and cereal moisture content on the grinding index and the grinding ability index of the hammer mill. It could be seen that the grinding index increased with increasing the moisture content and decreased with increasing sieve hole diameter, where it increased from 34.44 to $91.28 \mathrm{~kJ} \mathrm{~mm}^{0.5} / \mathrm{kg}$ at $4 \mathrm{~mm}$ hole diameter, from 20.02 to $45.17 \mathrm{~kJ} \mathrm{~mm} .0 .5 / \mathrm{kg}$ at $6 \mathrm{~mm}$ hole diameter and it increased from 12.35 to $23.31 \mathrm{~kJ} \mathrm{~mm} \mathrm{~m}^{0.5} / \mathrm{kg}$ at $8 \mathrm{~mm}$ sieve hole diameter when the moisture increased from 10 to $18 \%$. The increasing percentage was $62.27 \%$ at $4 \mathrm{~mm}$ hole diameter, $55.68 \%$ at $6 \mathrm{~mm}$ and $47.02 \%$ at $8 \mathrm{~mm}$ hole diameter. Meanwhile the reduction percentage due to the effect of sieve hole diameter was $64.14 \%$ at $10 \%$ moisture content, $68.51 \%$ at $14 \%$ moisture content and $74.46 \%$ at $18 \%$ moisture content.

Multiple regression was carried out to find a relationship between the grinding index and both the moisture content (10-18\%) and sieve hole diameter $(4-8 \mathrm{~mm})$. The most suitable form obtained was as follows:

$$
\mathrm{GI}=-11.03(\mathrm{Ds})+3.47(\mathrm{Mc})+53.41 \quad\left(\mathrm{R}^{2}\right)=0.83
$$

Where GI is the grinding index, $\mathrm{kJ} . \mathrm{mm}^{0.5} / \mathrm{kg}$.

The grinding ability index is an important indicator for the relationship between the required energy of grinding and the level of pulverization of ground cereal the results indicated that it ranged from 0.81 to $6.00 \mathrm{~kJ} / \mathrm{m}^{2}$ depending on the sieve hole diameter and the moisture content of the cereals. The results indicated that the grinding ability index increased with increasing the moisture content and decreased with increasing the sieve hole diameter, where it increased from 2.41 to $6.00 \mathrm{~kJ} / \mathrm{m}^{2}$ at $4 \mathrm{~mm}$ hole diameter, from 1.38 to $2.74 \mathrm{~kJ} / \mathrm{m}^{2}$ at $6 \mathrm{~mm}$ hole diameter and it increased from 0.81 to $1.31 \mathrm{~kJ} / \mathrm{m}^{2}$ at $8 \mathrm{~mm}$ sieve hole diameter when the moisture increased from 10 to $18 \%$. The increasing percentage was $59.83 \%$ at $4 \mathrm{~mm}$ hole diameter, $49.64 \%$ at $6 \mathrm{~mm}$ and $38.17 \%$ at $8 \mathrm{~mm}$ hole diameter. Meanwhile the reduction percentage due to the effect of sieve hole diameter was $66.39 \%$ at $10 \%$ moisture content, $71.12 \%$ at $14 \%$ moisture content and $78.17 \%$ at $18 \%$ moisture content. The results are similar to these reported by [23].

Multiple regression was carried out to find a relationship between

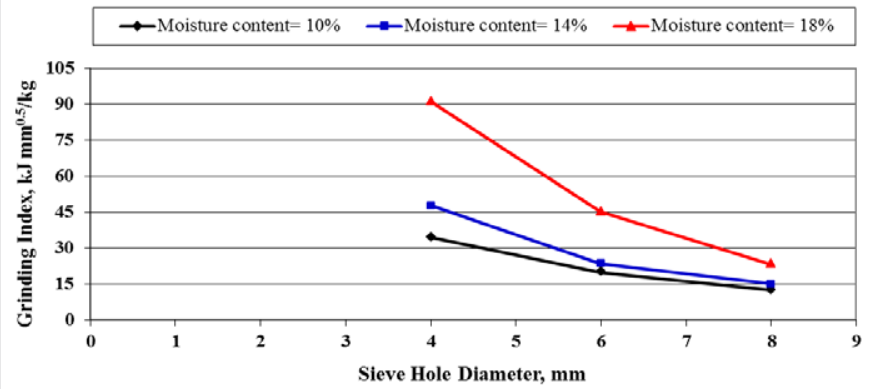

Figure 5: Effect of moisture content and sieve holes diameter on grinding index.

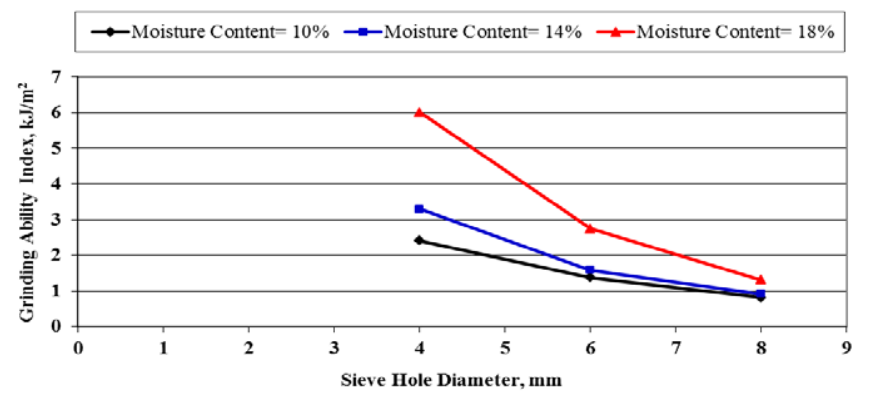

Figure 6: Effect of moisture content and sieve holes diameter on grinding ability index. 
the grinding ability index and both the moisture content (10-18\%) and sieve hole diameter $(4-8 \mathrm{~mm})$. the most suitable form obtained was as follows:

$$
\mathrm{GAI}=-0.78(\mathrm{Ds})+0.20(\mathrm{Mc})+4.26 \quad\left(\mathrm{R}^{2}\right)=0.83
$$

Where GAI is the grinding ability index, $\mathrm{kJ} / \mathrm{m}^{2}$.

\section{The ground quality}

Product mean weight diameter and size reduction: Figures 7 and 8 show the effect of sieve hole diameter and cereal moisture content on the product mean weight diameter and size reduction of the hammer mill. It could be seen that the product mean weight diameter increased with increasing the moisture content and increased by increasing sieve hole diameter where it increased from 1.47 to $1.91 \mathrm{~mm}$ at $4 \mathrm{~mm}$ hole diameter, from 1.81 to $2.16 \mathrm{~mm}$ at $6 \mathrm{~mm}$ hole diameter and it increased from 2.45 to 2.89 at $8 \mathrm{~mm}$ sieve hole diameter when the moisture increased from 10 to $18 \%$. The increasing percentage was $23.04 \%$ at 4 $\mathrm{mm}$ hole diameter, $16.20 \%$ at $6 \mathrm{~mm}$ and $15.22 \%$ at $8 \mathrm{~mm}$ hole diameter. Meanwhile the increasing percentage due to the effect of sieve hole diameter was $40.00 \%$ at $10 \%$ moisture content, $36.15 \%$ at $14 \%$ moisture content and $33.91 \%$ at $18 \%$ moisture content.

Multiple regression was carried out to find a relationship between the product weight mean diameter and both the moisture content (10$18 \%)$ and sieve hole diameter (4-8 $\mathrm{mm})$ using sieve the most suitable form obtained was as follows:

$\mathrm{MWD}=0.25(\mathrm{Ds})+0.06(\mathrm{Mc})-0.22$

$\left(\mathrm{R}^{2}\right)=0.93$

Where MWD is the product mean weight diameter, $\mathrm{mm}$.

Regarding the size reduction, the results indicated that the size reduction decreased with increasing both the moisture content and sieve hole diameter, where it decreased from 5.10 to 3.93 times at 4 $\mathrm{mm}$ hole diameter, from 4.14 to 3.47 times at $6 \mathrm{~mm}$ hole diameter and it decreased from 3.11 to 2.70 times at $8 \mathrm{~mm}$ sieve hole diameter when the moisture increased from 10 to $18 \%$. The reduction ratio percentage was $22.94 \%$ at $4 \mathrm{~mm}$ hole diameter, $16.18 \%$ at $6 \mathrm{~mm}$ and $13.18 \%$ at $8 \mathrm{~mm}$ hole diameter. Meanwhile the reduction percentage due to the effect of sieve hole diameter was $39.02 \%$ at $10 \%$ moisture content, $32.08 \%$ at $14 \%$ moisture content and $31 \%$ at $18 \%$ moisture content.

Multiple regression was carried out to find a relationship between the size reduction and both the moisture content (10-18\%) and sieve hole diameter $(4-8 \mathrm{~mm})$. The most suitable form obtained was as follows:

$$
\mathrm{S}_{\mathrm{R}}=-0.40(\mathrm{Ds})-0.09(\mathrm{Mc})+7.30
$$$$
\left(R^{2}\right)=0.94
$$

Where $S_{R}$ is the size reduction, times.

From the results, it could be concluded that the mean weight diameter ranged from 1.47 to $2.89 \mathrm{~mm}$ as the sieve hole diameter changed from 4 to $8 \mathrm{~mm}$. on the other hand, the size reduction reached as high 5.10 times to as low as 2.60 as the sieve hole diameter changed from 4 to $8 \mathrm{~m}$ with different moisture content (10-18\%).

Fineness degree (Particle size distribution): Figure 9 shows the effect of sieve hole diameter and cereal moisture content on the fineness degree. It could be seen that the increase of grains moisture content caused a decrease in percentage of fine milled corn (FMC), while percentage of coarse milled corn (CMC) increases. The obtained results show that, decrease percentage of (FMC) from 38.34 to $30.34 \%$ at $4 \mathrm{~mm}$ hole diameter, from 32.82 to $28.17 \%$ at $6 \mathrm{~mm}$ hole diameter and it decreased from 25.50 to $17.50 \%$ at $8 \mathrm{~mm}$ hole diameter, while the percentage of (CMC) increase from 5.50 to $19.33 \%$ at $4 \mathrm{~mm}$ hole diameter, from 16.33 to $28.67 \%$ at $6 \mathrm{~mm}$ hole diameter and it increased from 37.17 to $48.17 \%$ at $8 \mathrm{~mm}$ hole diameter. Also it noticed that the increase of sieve hole diameter caused a decrease in percentage of (FMC), while percentage of coarse milled corn (CMC) increases.

Therefore, it can be concluded that the percentage of fin grinding is inversely proportional with the sieve hole diameter and grain moisture content. This can be explained by the fact that the resistance force decreases when the hole diameter increases and material can easily pass through the sieve hole diameter without much friction. These results trend agreed with those obtained by [24].

Bulk density: Figure 10 shows the effect of sieve hole diameter and cereal moisture content on the bulk density of corn crushed. It could be seen that the bulk density decreased with increasing the moisture content and decreased by increasing sieve hole diameter, where it decreased from 621.34 to $575.08 \mathrm{~kg} / \mathrm{m}^{3}$ at $4 \mathrm{~mm}$ hole diameter, from

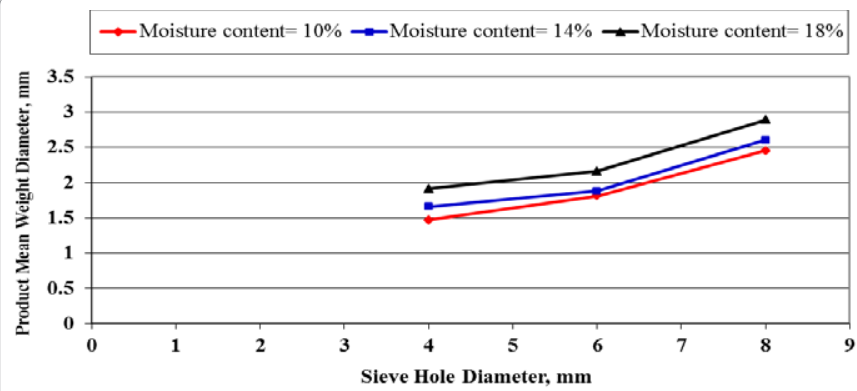

Figure 7: Effect of moisture content and sieve holes diameter on product mean weight diameter.

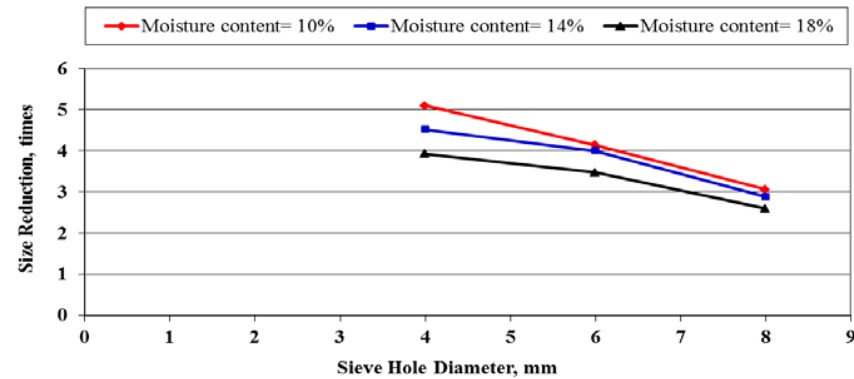

Figure 8: Effect of moisture content and sieve holes diameter on sizereduction.

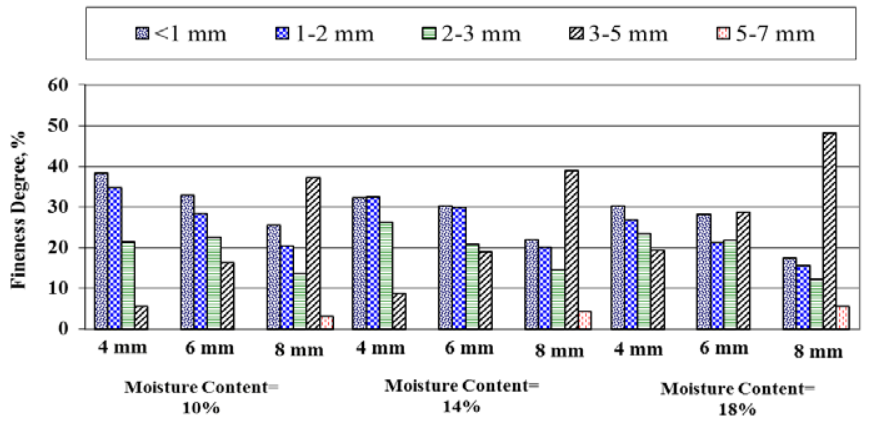

Figure 9: Effectof sieve hole diameter and cereal moisture contenton thefineness degree. 


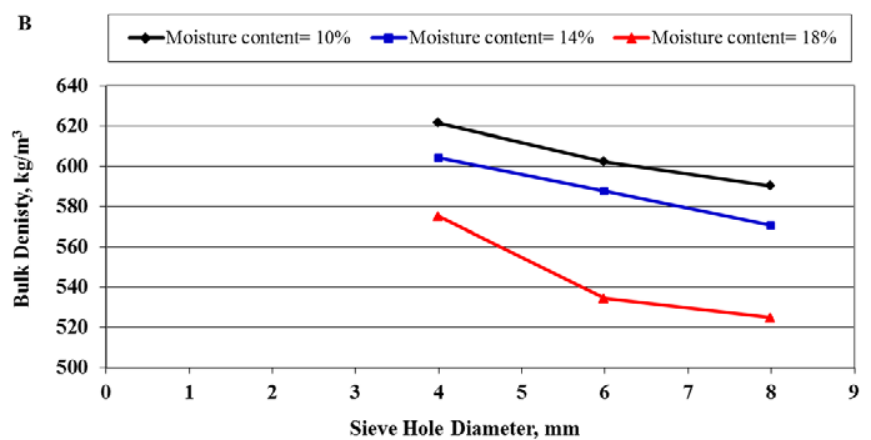

Figure 10: Effect of moisture content and sieve holes diameter on bulk density of corn crushed.

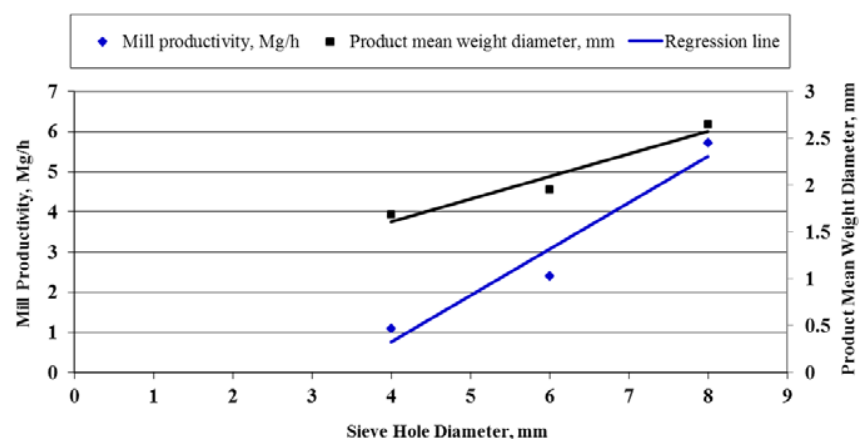

Figure 11: The relationship between the mill sieve hole diameter and both mill productivityand product mean weight diameter.

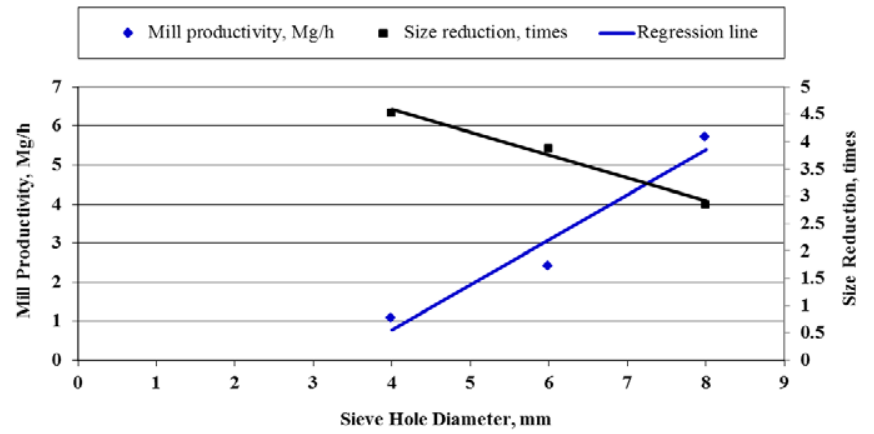

Figure 12: The relationship between the mill sieve hole diameter and both size reduction and mill productivity.

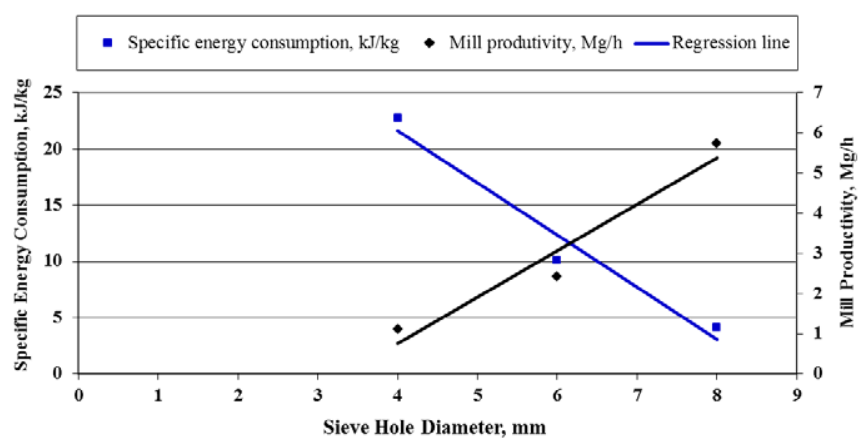

Figure 13: The relationship between the mill sieve hole diameter and both mill productivity and specific energy consumption of grinding.
602.17 to $534.28 \mathrm{~kg} / \mathrm{m}^{3}$ at $6 \mathrm{~mm}$ hole diameter and it decreased from 590.20 to $524.58 \mathrm{~kg} / \mathrm{m}^{3}$ at $8 \mathrm{~mm}$ sieve hole diameter when the moisture increased from 10 to $18 \%$. The reduction percentage was $7.45 \%$ at 4 $\mathrm{mm}$ hole diameter, $11.27 \%$ at $6 \mathrm{~mm}$ and $11.12 \%$ at $8 \mathrm{~mm}$ hole diameter. Meanwhile the reduction percentage due to the effect of sieve hole diameter was $5.01 \%$ at $10 \%$ moisture content, $5.60 \%$ at $14 \%$ moisture content and $8.78 \%$ at $18 \%$ moisture content (Figures $11-13$ ).

This was due to the fact that an increase in mass owing to moisture gain in the sample was lower than accompanying volumetric expansion of the bulk [25].

Multiple regression was carried out to find a relationship between the bulk density and both the moisture content (10-18\%) and sieve hole diameter $(4-8 \mathrm{~mm})$. the most suitable form obtained was as follows:

$$
\rho=-9.62(\mathrm{Ds})-7.49(\mathrm{Mc})+741.44 \quad\left(\mathrm{R}^{2}\right)=0.93
$$

Where $\rho$ is thebulk density, $\mathrm{kg} / \mathrm{m}^{3}$

Grinding effectiveness: Table 2 shows the effect of sieve hole diameter and cereal moisture content on the grinding effectiveness of the hammer mill. It could be seen that the grinding effectiveness decreased with increasing the sieve hole diameter, where it decreased from 14.40 to 8.88 at $10 \%$ moisture content, from 13.74 to 9.08 at $14 \%$ moisture content and it decreased from 13.47 to 9.82 at $18 \%$ moisture content when the sieve hole diameter increased from 4 to $8 \mathrm{~mm}$. The reduction percentage was $38.33 \%$ at $10 \%$ moisture content, $33.92 \%$ at $14 \%$ and $27.10 \%$ at $18 \%$ moisture content.

Multiple regression was carried out to find a relationship between the grinding effectiveness and both the moisture content (10-18\%) and sieve hole diameter $(4-8 \mathrm{~mm})$. the most suitable form obtained was as follows:

$$
\mathrm{GE}=-1.15(\mathrm{Ds})+0.03(\mathrm{Mc})+18.24 \quad\left(\mathrm{R}^{2}\right)=0.93
$$

Where GE is the grinding effectiveness.

Regression was carried out to find a relationship between the mill sieve hole diameter and both mill productivity, specific energy consumption, product mean weight diameter and size reduction. The most suitable form obtained was as follows:

$$
\begin{array}{ll}
\text { SEC }=-4.65(\mathrm{Ds})+40.24 & \left(\mathrm{R}^{2}\right)=0.96 \\
\mathrm{Mp}=1.16(\mathrm{Ds})-3.86 & \left(\mathrm{R}^{2}\right)=0.94 \\
\mathrm{MWD}=0.24(\mathrm{Ds})+0.64 & \left(\mathrm{R}^{2}\right)=0.94 \\
\mathrm{~S}_{\mathrm{R}}=-0.42(\mathrm{Ds})+6.25 & \left(\mathrm{R}^{2}\right)=0.98
\end{array}
$$

Where:

SEC: specific energy consumption, $\mathrm{kJ} / \mathrm{kg}$.

Mp: mill productivity, $\mathrm{Mg} / \mathrm{h}$.

$\mathrm{S}_{\mathrm{R}}$ : size reduction, times.

Ds: sieve hole diameter, $\mathrm{mm}$.

MWD: product mean weight diameter, $\mathrm{mm}$.

\section{Conclusion}

- The highest performance $(6.83 \mathrm{Mg} / \mathrm{h})$ was obtained at $8 \mathrm{~mm}$ hole diameter and $10 \%$ moisture content which decreased to the lowest performance $(0.7 \mathrm{Mg} / \mathrm{h})$ which obtained at $4 \mathrm{~mm}$ hole diameter and $18 \%$ moisture content. 
Citation: Dabbour MI, Bahnasawy A, Ali S, El- HaddadZ (2015) Grinding Parameters and their Effects on the Quality of Corn for Feed Processing. J Food Process Technol 6: 482. doi:10.4172/2157-7110.1000482

Page 7 of 7

\begin{tabular}{|c|c|c|c|c|c|c|c|c|}
\hline $\begin{array}{l}\text { Sieve holes } \\
\text { diameter, mm }\end{array}$ & $\begin{array}{l}\text { Moisture } \\
\text { content, \% }\end{array}$ & $\begin{array}{l}\text { Surface area before } \\
\text { grinding, } \mathrm{mm}^{2}\end{array}$ & WSG, $\mathbf{g}$ & WSP, $\mathbf{g}$ & MWD, mm & $\begin{array}{l}\text { Number of } \\
\text { particles (N) }\end{array}$ & $\begin{array}{l}\text { Surface area after } \\
\text { grinding, } \mathrm{mm}^{2}\end{array}$ & $\begin{array}{c}\text { Grinding } \\
\text { effectiveness }\end{array}$ \\
\hline \multirow{3}{*}{4} & 10 & 127.26 & 0.27 & 0.001 & 1.47 & 270 & 1832.01 & 14.4 \\
\hline & 14 & 134.92 & 0.3 & 0.0014 & 1.66 & 214.29 & 1854.16 & 13.74 \\
\hline & 18 & 145.74 & 0.36 & 0.0021 & 1.91 & 171.43 & 1963.74 & 13.47 \\
\hline \multirow{3}{*}{6} & 10 & 127.26 & 0.27 & 0.0018 & 1.81 & 150 & 1543.04 & 12.12 \\
\hline & 14 & 134.92 & 0.3 & 0.0021 & 1.88 & 142.86 & 1585.46 & 11.75 \\
\hline & 18 & 145.74 & 0.36 & 0.0028 & 2.16 & 128.57 & 1883.55 & 12.92 \\
\hline \multirow{3}{*}{8} & 10 & 127.26 & 0.27 & 0.0045 & 2.45 & 60 & 1130.87 & 8.88 \\
\hline & 14 & 134.92 & 0.3 & 0.0052 & 2.6 & 57.7 & 1224.76 & 9.08 \\
\hline & 18 & 145.74 & 0.36 & 0.0066 & 2.89 & 54.55 & 1430.61 & 9.82 \\
\hline
\end{tabular}

WSG: weight of single grain and WSP: weight of single particle

Table 2: Effect of sieve hole diameter and cereal moisture content on the grinding effectiveness.

- The highest specific energy, energy density consumption, grinding index and grinding ability index $32.72 \mathrm{~kJ} / \mathrm{kg}, 18.82$ $\mathrm{MJ} / \mathrm{m}^{3}, 91.28 \mathrm{~kJ} . \mathrm{mm}^{0.5} / \mathrm{kg}$ and $6.00 \mathrm{~kJ} / \mathrm{m}^{2}$, respectively were obtained at $4 \mathrm{~mm}$ hole diameter and $18 \%$ moisture content which decreased to the lowest specific energy and energy densityconsumption, grinding index and grinding ability index $3.38 \mathrm{~kJ} / \mathrm{kg}, 1.99 \mathrm{MJ} / \mathrm{m}^{3}, 12.35 \mathrm{~kJ} \cdot \mathrm{mm}^{0.5} / \mathrm{kg}$ and $0.81 \mathrm{~kJ} / \mathrm{m}^{2}$, respectively at $8 \mathrm{~mm}$ hole diameter and $10 \%$ moisture content.

- The ground product

- The highest mean weight diameter $(2.89 \mathrm{~mm})$ was obtained at 8 $\mathrm{mm}$ hole diameter and $18 \%$ moisture content which decreased to the lowest mean weight diameter $(1.47 \mathrm{~mm})$ which obtained at 4 $\mathrm{mm}$ hole diameter and $10 \%$ moisture content.

- The highest size reduction and bulk density 5.10 times and 621.34 $\mathrm{kg} / \mathrm{m}^{3}$, respectively was obtained at $4 \mathrm{~mm}$ hole diameter and $10 \%$ moisture content which decreased to the lowest size reduction and bulk density 2.60 times and $524.58 \mathrm{~kg} / \mathrm{m}^{3}$, respectively which obtained at $8 \mathrm{~mm}$ hole diameter and $18 \%$ moisture content.

- The highest grinding effectiveness (14.40) was obtained at $4 \mathrm{~mm}$ hole diameter and $10 \%$ moisture content which decreased to the lowest grinding effectiveness (8.88) which obtained at $8 \mathrm{~mm}$ hole diameter and $10 \%$ moisture content.

\section{References}

1. Glenn GM, Johnston RK (1992) Moisture-dependent changes in the mechanical properties of isolated wheat. J. Cereal Sci 15: 223-236.

2. Mabille F, Gril J, Abecassis J (2001) Mechanical properties of wheat seed coat. Cereal Chem 78: 231-235.

3. Gehle H (1965) The MIAG "Vario" Rollstand: Design and purpose.

4. Kilborn RH, Black HC, Dexter JE, Martin DG (1982) Energy consumption during flourmilling. Description of two measuring systems and influence of wheat hardness on the energy requirements. Cereal Chemistry 59: 284-288.

5. Fang Q (1995) Effects of physical properties of wheat and operational parameters of roller millson size reduction.

6. Pujol R, Letang C, Lempereur I, Chaurand M, Mabille F, et al. (2000) Description of a micro mill with instrumentation for measuring grinding characteristics of wheat grain. Cereal Chem 77: 421- 427.

7. Hassan MA (1994) Modifying and evaluation a small locally made mix-milling unit suitable for Egyptian poultry farms. Misr J Ag Eng 11:569 -584.

8. Vigneault C, Rothwell TM, Bourgeois GB (1992) Hammer mill grinding rate and energy requirements for thin and conventional hammers. Canadian Agricultura Engineering 34: 203-207.
9. Dziki D (2008) The crushing of wheat kernels and its consequence on the grinding process. Powder Technology 185: 181-186.

10. Dziki D, Laskowski J (2006) Influence of wheat grain mechanical properties on grinding energy requirements. TEKA Kom Mot Energ Roln 6A: 45- 52.

11. Mani S, Tabil LG, Sokhansanj S (2004) Grinding performance and physical propertiesof wheat and barley straws, corn stover andswitchgrass. Biomass Bioenergy 27: 339- 352.

12. Egela MI, Sharobeem YF, Badawy ME (2003) Modification of some operational parameters for local manufactured hammer mill. The 11th annual conference of Misr Society of Ag. Eng.

13. Kurt G, Gieck R (1979) Engineering formulas. McGraw Hill book Co., USA

14. Metwally KA (2010) Study the effect of some operational Factors on hammer mill.

15. Velu V, Nagender A, Prabhakara PG, Rao DG (2006) Dry milling characteristic of microwave dried maize grains(Zea mays L.). Journal of Food Engineering 74: 30-36.

16. Perry RH, Green DW (1984)Perry's chemical engineers' handbook. McGrawHill Book Company, New York.

17. Dziki D, Laskowski J (2000)Badaniewłaściwościprzemiałowychwybranychodm ianpszenicy. InŜynieria Rolnicza 8: 63-69.

18. Sokołowski M (1996) Energy consumed in grinding- a new idea of a general law of comminution-new tests stands and testing results. Recents Progress en Genie Procedes 10: 221-226.

19. Balasubramanian S, Sharma R, Vijay Kumar SR (2011)Effect of moisture content and feed rate on size reduction of pearl millet. Journal of Food Science and Engineering 1: 93- 99

20. Jain RK, Bal S (1997) Properties of pearl millet. Journal of Agricultural Engineering Research 66: 85-91.

21. Dziki D, Laskowski J (2005) Influence of selected factors on wheatgrinding energy requirements. TEKA Kom Mot Energ Roln 5: 56- 64.

22. Annoussamy M, Richard G, Recous S, Guerif J (2000) Change in mechanical properties of wheat straw due to decomposition and moisture. Applied Engineering in Agriculture 16: 657- 664

23. Dziki D, Laskowski J (2010) Study to analyze the influence of sprouting of the wheat grain on the grinding process. Journal of Food Engineering 96: 562-567.

24. Abdel Mottaleb AF, EL Dahshan WA, Bejo L (2009) Optimization of milling farm residues using a local hammer mill. Farm Machinery and Power of Misr $\mathrm{J}$ Ag Eng 26: 1172-1189.

25. Pradhan RC, Naik SN, Bhatnagar N, Swain SK (2008) Moisture-dependent physical properties of Karanja (Pongamiapinnata) kernel. Industrial Crops and Products 28: 155-161. 